\section{Géneros}

Multidisciplinary Journal of Gender: Studies

\section{Hipatia Press \\ www.hipatiapress.com}

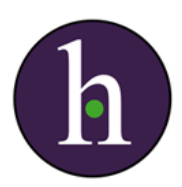

Instructions for authors, subscriptions and further details:

http://generos.hipatiapress.com

\title{
Gender, Identity, and Language Use in Web Discussion Forum and Mobile Phone Txt Messages
}

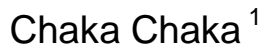

1) University of South Africa. South Africa

Date of publication: October $25^{\text {th }}, 2016$

Edition period: October - February 2017

To cite this article: Chaka, Ch. (2016). Gender, Identity, and Language Use in Web Discussion Forum and Mobile Phone Txt Messages.

Multidisciplinary Journal of Gender Studies, 5(3), 1126-1151. doi:

10.4471/generos.2016.1477

To link this article: http://dx.doi.org/10.4471/generos.2016.1477

\section{PLEASE SCROLL DOWN FOR ARTICLE}

The terms and conditions of use are related to the Open Journal System and to Creative Commons Attribution License (CC-BY). 


\section{Gender, Identity, and Language Use in Web Discussion Forum and Mobile Phone Txt Messages}

Chaka Chaka

University of South Africa

\section{Abstract}

This study explored and compared both online and txt (text) messaging gender and identity construction and language use among adult males and females. The online gender and identity construction and language use concerned adult males and females who participated in a web discussion forum (WDF) while the txt messaging gender and identity construction and language use related to adult male and female users of mobile technologies from South Africa. Online and MP txt messaging gender and identity construction and language use were examined in terms of the disclosure of personal information, sexual identity, emotive features and semantic themes (Huffaker \& Calvert, 2005). Some of the findings of this study are as follows: both females and males investigated tended to construct their identities both similarly and differently depending on the form of technology employed; in both the WDF and MP messages, more females tended to employ emoticons than did males and the same was true of the emotive traits related to expressive language; the two genders engaged in intimate topics in varying degrees; and both genders seemed to employ passive and cooperative language very nearly similarly.

Keywords: gender, identity, language use, web discussion forum, txt messages 


\section{Género, Identidad y Uso del Lenguaje en Fórums Web y Mensajes de Texto Móviles}

Chaka Chaka

University of South Africa

\section{Resumen}

Este estudio explora y compara tanto la construcción de la identidad y del género como el uso del lenguaje en mensajes en línea y de texto ( $t x t)$ por parte de hombres y mujeres adultos. El análisis de la construcción de la identidad y del género así como el uso del lenguaje realizado online implicó a hombres y mujeres adultos participantes en un Foro de Discusión Web (WDF); mientras que el análisis de la construcción de la identidad y del género y el uso del lenguaje en los mensajes de texto implicó a usuarios y usuarias de tecnología móvil en Sudáfrica. La construcción de la identidad y el género y el uso del lenguaje en mensajes online y de texto fueron analizados a partir de las categorías de divulgación de información personal, identidad sexual, características emocionales y temas semánticos (Huffaker \& Calvert, 2005). Algunos de los hallazgos de este estudio son: tanto los hombres como las mujeres investigados tienden a construir sus identidades de manera similar y diferente en función de la tecnología empleada; tanto en la WDF como en los mensajes $t x t$, las mujeres tendieron a utilizar más emoticonos que los hombres y lo mismo sucedió con la expresión de emociones; ambos sexos abordaron temas íntimos en diversos grados; y ambos sexos parecieron emplear de manera casi similar el lenguaje pasivo y cooperativo.

Palabras clave: género, identidad, uso del lenguaje, fórum web, mensajes de texto 
ender, identity and language are mainly conceptualised as interconnected. In much gender and identity studies literature (Cameron, 1998; Lewis \& Mills, 2003; Mills, 2003a, b, c; Wodak, 1997), both gender and identity are theorised as implicated in and constructed through language. Three perspectives offer, in varying degrees, the insight into this theorisation of gender and identity. For example, the difference perspective maintains that men and women assume unitary identities specific to their respective gender positioning and, as such, tend to use language differently because of the differential socialisation patterns to which they are exposed and subjected.

Concomitantly, this standpoint embodies two crucial but controversial assertions. First, it asserts that the different linguistic styles of interacting and of creating meaning are grounded in the different cultural practices into which both men and women are inducted. Second, it posits that women are often disadvantaged by these linguistic styles as the systems of communication within which they learn to interact, make them acquiesce in the existing patriarchal status quo. That is, they make them want to be nice and to choose the prestige of goodness over the prestige of power (Crawford, 1995; Huffaker \& Calvert, 2005; Lakoff, 1975; Sadiqi, 2003; Simpson, 1997; Tannen, 1990).

A second view of the linguistic constitution of gender and identity is a feminist poststructuralist perspective. Besides positing gendered subjectivities and subject positions that are constituted through discourse, this approach proposes multiple femininities/masculinities and strongly disagrees with the difference framework. It regards the latter as being unable to theorise the complex dynamics of power, gender and identity sufficiently and as unnecessarily valorising the classical dualisms built into a patriarchal society (Bhabha, 1994; Simpson, 1997; Poynton, 1993; Weedon, 1987). Related to this second view is the third one, the social construction paradigm. According to this paradigm, gendered identities and other aspects of social identity are (re-)constructed and (re-)created through both social and language practices (Bucholtz, 1999; Burgess, 2002; Butler, 1997; Cameron, 1998; Piller, 2001).

The current study aligns itself with the third view of theorising gender and identity. Thus, its purpose is to investigate how web discussion forum 

Messages

and mobile phone users employ language and emotional codes to express their genders and identities (Calcutt, 2001; Herring, Kouper, Scheidt \& Wright, 2004; Huffaker, 2004; Leung \& Wei, 2000; Ling \& Yttri, 2002; Thurlow \& Brown, 2003; Thurlow, Lengel \& Tomic, 2004).

\section{Framing Issues}

In the light of the above, in this study, both gender and identity are conceptualised within a feminist-postmodernist framework. This represents a synergy between feminist and postmodernist theory. While it is not the major thrust of this article to engage in a definitional debate on feminism and postmodernism - as they are both typified by disparate strands, ontologies and epistemologies (Burgess, 2002; Cameron, 1992, 1998; Erasmus, 1998; Griffiths, 1995; Lather, 1992; Luke, 1992) - it is essential to briefly provide a perspective in which these two concepts are used and the rationale behind combining them in this context. Feminism challenges, opposes and critiques the different forms of oppression and discrimination (social, cultural, linguistic, institutional, etc.), and the differential treatment to which women are subjected. It rejects all patriarchal practices underpinning all forms of malestream tendencies and calls for their total eradication. It fights for women's place in society and problematises the notions of sex, gender, sexism and sexuality. For its part, postmodernism challenges and critiques foundational knowledge and meta-narratives (e.g. objectivity, neutrality, universality of knowledge, etc.), and the static self or subjectivity. In addition, it espouses fragmentation, difference and multiplicity - partial knowledges, multiple (and fluid) subjectivities and identities - (Cameron, 1992, 1997; Griffiths, 1995; Piller, 2001; Mills, 2003a, b, c; Swann, 2002).

Thus, the interface between feminism and postmodernism is brought about by the fact that feminism provides postmodernism with conceptual tools to critique malestream practices while postmodernism offers feminism conceptual tools to critique foundational knowledge practices. The interface is also brought about by the fact that both feminism and postmodernism are concerned with the politics of identity and subjectivity and that both reject dualisms - e.g. man/woman, mind/body, subject/object, etc. - which are at the core of much of modernist thought and much of the modern study of 
language (Bhabha, 1994; Cameron, 1997, 1998; Turkle, 1996; Wodak, 1997). It is this combination of conceptual tools as offered by these two theoretical epistemologies through which I investigate gender, identity and language use in web discussion and $t x t$ messages.

\section{Digital Online Gender and Identity}

Both digital online gender and identity are more complex and hybrid than is generally thought. That is, besides being complex and hybrid in character, they also tend to assume fluid, contingent, shifting, and multiple digital configurations. In addition, they tend to be packaged and presented as images and information permeating spatio-temporal boundaries with everimposing ubiquity. This is hardly surprising as digital online gender and identity tend to be, to some extent, dependent on the digital and mobile communications technologies - e.g. the Internet, e-mail and handheld mobile technologies - through which they are mediated (Castells, 2000; Donath, 1996; Jones, 1997; Marney, 2005; Stalder, 2000; Tapscott, 1998; Turkle, 1995, 1996).

The scenario outlined above is much more applicable to online chat, newsgroups, bulletin boards, web discussion forums, txt messages (short messaging services - SMSs) and instant messaging texts mediated through web-based e-mail and mobile phone technologies. Here users' genders and identities not only become complex, hybrid, fluid and shifting, but do also become truly digitally diasporic (Diamandaki, 2003; Rassool, 1999) and cosmopolitan entities inhabiting the same and different spatio-temporal homes simultaneously. This whole configuration entails a shifting digital ethoscope in which online users, (signed-up and non-signed-up) guests, tourists, immigrants, refugees, exiles, etc. (Microsoft Corporation, 2005; Rassool, 1999), rebels and other groups constitute a cyberspatial diaspora. It is in this cyberspatial environment that the linguistic, discursive and social construction of gender and identity and the digital construction of gender and identity meet each other. In this environment, the types of genders and identities displayed, and the nature of the language used have to be treated with circumspection. 
1131 Chaka-Gender, Identity, and Language Use in WDF \& Txt Messages

\section{Research Methods}

\section{Purpose}

As is the case with Huffaker and Calvert's (2005) study in particular, the purpose of my study was to explore gender and identity similarities and differences among adult users of both web discussion forums and mobile phone txt messages. In addition, the study examined how these users employ language and emoticons to present their identities and to express their personal feelings and experiences through these two forms of technologies. Following Huffaker and Calvert's (2005) study again, the focal areas here were: 1) the degree to which personal data - e.g. names, locations and contact information - was disclosed; 2) how emotive features were relayed; 3) how language was used to communicate experiences, feelings and ideas; 4 ) and how issues of sexual identity were intimated.

\section{Hypotheses}

In view of the above, the study set out to test the following four hypotheses:

$H_{1:} \quad$ Both males and females are likely to present themselves similarly in their messages often disclosing personal information such as either their real names, identity (ID) user names, or digital fake identities (pseudonyms), locations, and personal background details such as their current jobs, professions and careers.

$\mathrm{H}_{2}$ : $\quad$ Males tend to use less emoticons - and thus less expressive language - and tend to employ more active and resolute style of language than do females.

$H_{3}$ : Females tend to discuss intimate topics more openly than males.

$H_{4}$ : Females are more likely to use language that is passive, cooperative and accommodating than do males. 


\section{Sampling and Data Collection Method}

Data (txt messages) for this study were selected randomly at different times from three groups of participants: Becomingwebhead participants; the South African Broadcasting Corporation's SABC 1's One music programme's viewers; and private mobile phone users. These data, then, comprised two types of corpora. The first corpus consisted of a sample of 1.200 messages posted to the web discussion forum (WDF), Becomingwebhead, of which I (the researcher) was a member. This WDF was an asynchronous web-based forum where participants posted their messages either to an electronic bulletin board or to members' e-mail addresses. Upon logging in, subscribed users were notified of the new postings or emails they had not yet accessed. As messages were saved in a log list, participants were able to enter into the discussions at intervals convenient to them (Murphy, 2001). The messages making part of this first corpus were collected over a period of three months, from December 2010 to February 2011 and were randomly selected from a database of 4.000 messages. Of the 1.200 messages, 600 were posted by female users and the other 600 were posted by male users.

The second corpus of the data was made up of two sets of $500 \mathrm{txt}$ messages (SMSs) which were collected over four months (from February 2006 to July 2006). Of these two sets of messages, 250 were sent by female and male users apiece for both sets. The first set of txt messages was obtained from the personal mobile phones of 10 private users in Mthatha (South Africa) who were asked to save, retrieve and transcribe (as accurately as possible) SMSs they received from adult senders over this period of time (see Farina \& Lyddy, 2011; Geertsema, Hyman \& Van Deventer, 2011; Katz \& Aakhus, 2002; Ling \& Yttri, 2002; Njemanze, 2012; Oyinloye, 2009; Thurlow \& Brown, 2003). The second set of $t x t$ messages was sourced from the SMSs the viewers sent to a South African television programme - One - hosted by the South African Broadcasting Corporation (SABC) TV channel $S A B C 1$ once per week. On this programme, which was a music programme meant for both youth and adult viewers across different age groups, viewers were invited to send dedication SMS messages devoted to their various family members including their loved ones. Once received, the messages were displayed several times on the TV screen. 


\section{Chaka-Gender, Identity, and Language Use in WDF \& Txt Messages}

\section{Data Analysis Model and Procedure}

Content, conversational and discourse analyses served as a model of analysis for the data used in this study. Content analysis involves identifying units of analysis and counting the number of frequencies certain words, items, or variables are used within a given context. It is an analytic approach based on coding and quantifying various elements in any kind of text (including online and txt messages) in any medium. Word, category and conceptual frequency analyses are some of its primary areas of focus. At the most basic level, the main purpose of this method is to locate the nature of the relative patterns within and between sets of data (Heckman \& Annabi, 2005; Huffaker \& Calvert, 2005; Lowe, 2003; Pachler \& Daly, 2009; Petrina, 1998).

For its part conversational analysis studies conversation and deals with such aspects as talk, conversation structure, adjacency pairs, preference, repairs, floor, turn-taking, and participants (Levinson, 1983; Norrick, 1991; Sacks, 1994). Similarly, discourse analysis in this case deals with features of discourse or language such as discourse markers, markers of similarities and differences between men's and women's language, and aspects of discourse or language reflecting the gender and identity of language users (Coates \&Cameron, 1988; Eckert \& McConnell-Ginet, 1999; Heckman \& Annabi, 2005; Herring, 2000; Huffaker \& Calvert, 2005; Lee, 2003; Lewis \& Mills, 2003; Mills, 2003a, c).

Regarding the procedure used in this study, all the three types of messages (web discussion forum -WDF - messages, personal mobile phone txt messages and viewers' mobile phone $t x t$ messages) were coded, scored and analysed for personally identifiable information, emotive features, sexual identity, and gendered language (see Calcutt, 2001; Heckman \& Annabi, 2005; Huffaker \& Calvert, 2005; Katz \& Aakhus, 2002; Ling \& Yttri, 2002). Tropes V6.2 and DICTION 5.0, two content analysis software packages designed to analyse documents in terms of word counts as well as content types and language tone, were used to determine the tone and semantic features of words (Heckman \& Annabi, 2005; Huffaker \& Calvert, 2005). In addition, both conversational and discourse analyses were conducted to examine how gender and identity markers were expressed by adult users of web discussion forum and mobile phone technologies. 


\section{Research Findings}

\section{Personal Self-Disclosure Data: WDF and MPs}

In keeping with the study format of Huffaker and Calvert (2005), each WDF message was analysed for the specific personal information disclosed by the user. This included full names (first and last names or either of the two), location (geographical place) and contact information (email address, ID user name, digital fake identity (pseudonym) or a URL to a home page or a hyperlink). The other aspect examined in each message was the disclosure of personal background information such as the user's current job, profession, career, etc. The inter-rater reliability (conducted by three scorers) for these aspects of the personal information variable for female users was as follows: first names $=98 \%$; full names $=96 \%$; locations $=$ $90 \%$; contact information $=90 \%$ (emails $=100 \%$; ID user names $=94 \%$; a URL to a home page or a hyperlink $=76 \%$ ); and personal background details (e.g. job, profession or career) $=84 \%$. For male users the inter-rater reliability for personal information and personal background variables was as follows: first names $=96 \%$; full names $=95 \%$; locations $=92 \%$; contact information $=89 \%$ (emails $=100 \%$; ID user names $=92 \%$; a URL to a home page or a hyperlink $=74 \%$ ); and personal background details $=88 \%$.

The content analysis of the aspects of the personal information variable highlighted above revealed the following pointers. WDF users disclose a considerable amount of information about themselves. The most revealed aspects of the personal information variable by both female and male users were, in their ordinal occurrence frequency: emails $=94 \%$; first names $=$ $87 \%$; full names $=82 \%$; ID user names $=80 \%$; locations $=78 \%$; personal background details (job, profession or career) $=60 \%$; and a URL to a home page or a hyperlink $=35 \%$. Frequencies for female users were as follows: emails $=94 \%$; first names $=88 \%$; full names $=84 \%$; ID user names $=84 \%$; locations $=78 \%$; personal background details $=60 \%$; and a URL to a home page or a hyperlink $=32 \%$. On the other hand, frequencies for male users displayed the following percentages: emails $=93 \%$; first names $=86 \%$; full names $=80 \%$; ID user names $=80 \%$; locations $=76 \%$; personal background details $=58 \%$; and a URL to a home page or a hyperlink $=$ $35 \%$. 
1135 Chaka-Gender, Identity, and Language Use in WDF \& Txt Messages

The same content analysis was carried out for MP messages. Here the inter-rater reliability for female users in both sets of the data was scored as follows for personal information: first names $=86 \%$; nicknames $=72 \%$; full names $=100 \%$; mobile phone numbers $=88 \%$; and locations $=94 \%$. The other elements of the personal data variable were not relevant as they did not apply to the MP usage environment. For male users in both sets of the data the inter-rater reliability was calculated thus: first names $=96 \%$; nicknames $=60 \%$; full names $=100 \%$; mobile phone numbers $=96 \%$; and locations $=96 \%$. The occurrence frequencies for both sets of female users were as follows - with the data from the SMSs sent to the 10 users' personal MPs reflected first and the data from the SMSs sent to the SABC's music programme One recorded second in each sub-variable, respectively: first names $=34 \% / 88 \%$; nicknames $=54 \% / 50 \%$; full names $=0 \% / 0 \%$; mobile phone numbers $=94 \% / 0 \%$; and locations $=0 \% / 90 \%$. Likewise, the usage frequencies for both sets of male users were as follows: first names $=$ 40\%/90\%; nicknames $=60 \% / 74 \%$; full names $=0 \% / 0 \%$; mobile phone numbers $=94 \% / 0 \%$; and locations $=0 \% / 92 \%$.

\section{Emotive Features: Emoticons and Typographic Symbols}

All the messages were analysed for the use and occurrence of emotive features such as emoticons (smileys) and typographic symbols. The occurrence frequency of both text-based and graphic emoticons as used in the various messages was tabulated. Table 1 below reflects the types of text-based and graphic emoticons used in the respective messages together with their occurrence frequencies. The contrast between the occurrence frequencies by both female and male users in respect of the WDF and MP messages was drawn (see Huffaker \& Calvert, 2005; Thurlow \& Brown, 2003). 
Table 1

Types and examples of text-based and graphic emoticons used in the WDF and MP messages

\begin{tabular}{|c|c|c|c|c|}
\hline Types of Emoticons? & Text-baseds & Graphicala & WDFMessages $(\mathrm{OFs}) * \Rightarrow$ & MPMes 5 ages $(\mathrm{OF} 5)^{+2}$ \\
\hline Happyः & $\therefore$ or $\because-9$ & 6 & $\mathrm{~F}=80 \% ; \mathrm{M}=10 \% \mathrm{\alpha}$ & $F=10 \% ; M=1 \% R$ \\
\hline Winking 7 & ;) or $\mathrm{Pa}$ & 68 & $\mathrm{~F} \cdot=60 \% ; \mathrm{M}=15 \% \mathrm{R}$ & $\mathrm{F}=2 \% ; \mathrm{M}=-1 \% \mathrm{R}$ \\
\hline Crying? & $\therefore \sim(\sim-\mathrm{or}: \sim(\sim \sim)$ & (4) & $\mathrm{F}=10 \% ; \mathrm{M}=0 \% \mathrm{R}$ & $\mathrm{F}:=0 \% ; \mathrm{M}=.0 \% \mathrm{R}$ \\
\hline Sad $=$ & $\therefore$ (or:- $(a)$ & & $\mathrm{F}=45 \% ; M=2 \%$ & $\mathrm{~F}=0 \% ; \mathrm{M}=.0 \% \mathrm{R}$ \\
\hline
\end{tabular}

$*=$ Occurrence frequencies

The types of typographic symbols used in the WDF messages - together with their corresponding frequencies of occurrence - by both females and males are displayed in Table 2:

Table 2:

The types of typographic symbols used in the WDF messages by both females and males

\begin{tabular}{|c|c|c|}
\hline Typographical Symbols? & Descriptions & WDFMes sages $(\mathrm{OF} \text { s })^{\star x}$ \\
\hline 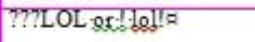 & Laughing out louds & $F=44 \% ; M=6 \% \pi$ \\
\hline 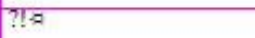 & Uncertaintya & $F=28 \% ; M=0 \% a$ \\
\hline$\cdots$ or $\ldots g$ & Pause & $F \cdot=-16 \% ; M=0 \% a$ \\
\hline ... Hmmmm orumpm? & Surprise/Excitement $\$$ & $\mathrm{~F}=32 \% ; \mathrm{M}=-1 \% \Omega$ \\
\hline 2009 & Reminder7 & $F=1 \% ; M=.0 \% R$ \\
\hline
\end{tabular}

$*=$ Occurrence frequencies

\section{Emotive Language}

Emotive language is an expressive language characterised by a high emotive content. It is intended to express human emotions and generate greater affective responses from readers in much the same way as emoticons or smileys do in the context of email and MP messages (Crystal, 2001; D’Addario, n.d.; Liwei, 2001; Herring, 2000; McArthur, 2000; 
1137 Chaka-Gender, Identity, and Language Use in WDF \& Txt Messages

Persson, 2003). This type of language can be used, among other things, to express feelings, moods and attitudes; it can also be employed to express happiness, excitement, humour, sarcasm, anxiety, anger, appreciation, and gratitude. Above all, it can be used for apologising, flirting, joking and insulting, etc. All these emotive variables are regarded as dependent measures by D'Addario (n.d.) and Huffaker and Calvert (2005). In the same vein, these variables were regarded as dependent measures in this study.

In the present study, the dependent emotive measures identified in the messages of both WDF and MP users were: gratitude, appreciation, happiness, excitement, apologising, humour, and joking. However, it is worth pointing out that these were much more predominant in the WDF messages than in the MP messages where they were hardly ever used. Consequently, Figure 1 shows the occurrence frequencies of these variables as used primarily in the WDF messages.

\section{Figure 1}

The percentage occurrence frequencies of the emotive variables as used mainly by females and males in the WDF messages

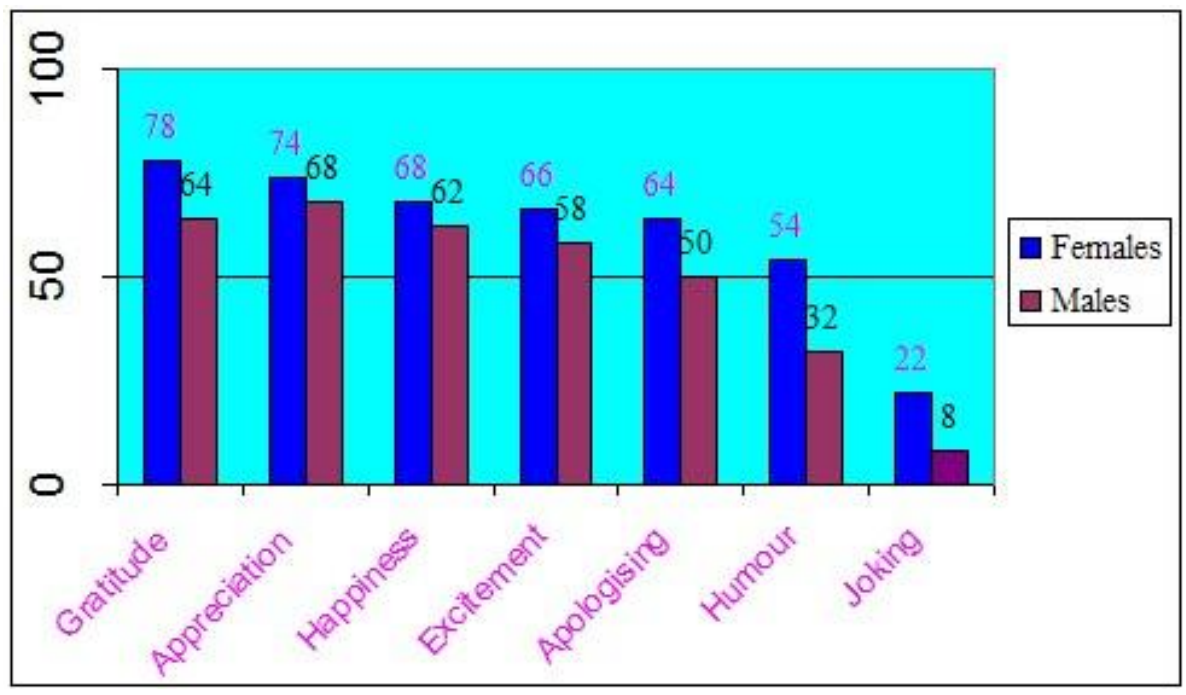




\section{Intimate Topics}

Some of the significant intimate topics discussed by the WDF users included greetings, food and recipes, blogging, colour and design, viruses and hoaxes, and andragogy. The MP users mainly engaged in greetings, well-wishing, love and personal relationship topics. Figure 2 below indicates the percentage discussion frequencies of the intimate topics by both female and male users in the WDF.

Figure 2

The percentage discussion frequencies of the intimate topics by both female and male users in the WDF

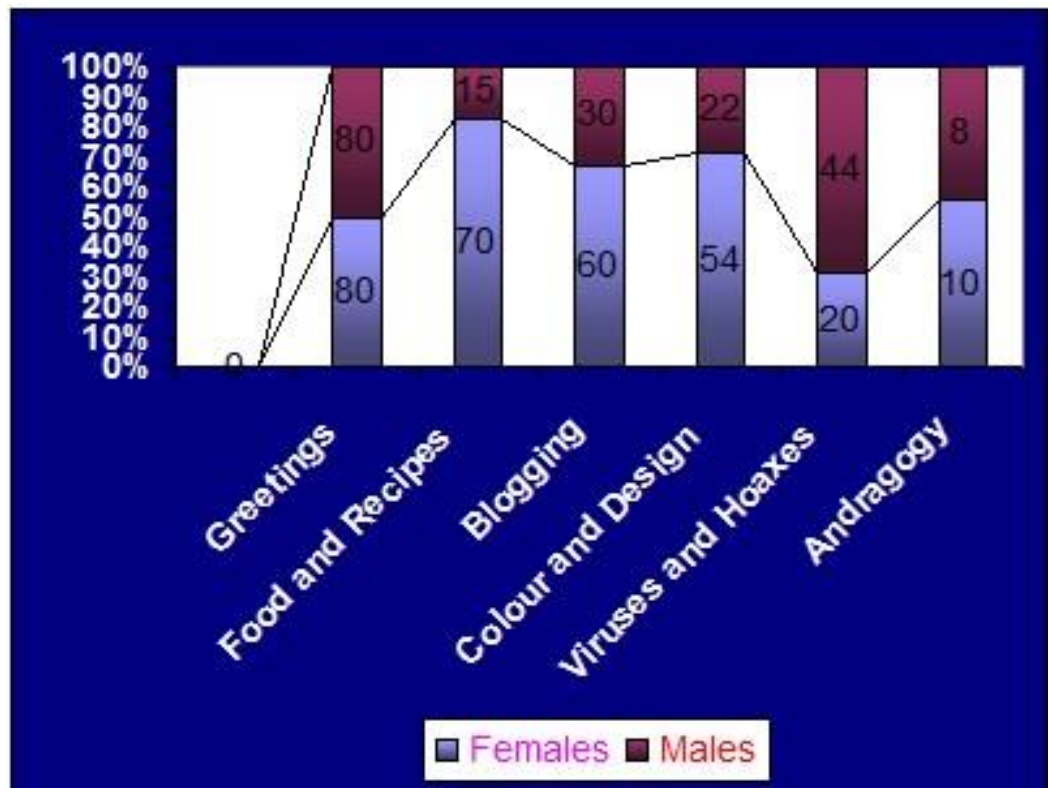

On the other hand, Figure 3 displays the percentage usage frequencies of the intimate topics discussed by all the MP users. 
1139 Chaka-Gender, Identity, and Language Use in WDF \& Txt Messages

Figure 3

The percentage usage frequencies of intimate topics in personal and SABC 1 One MP messages

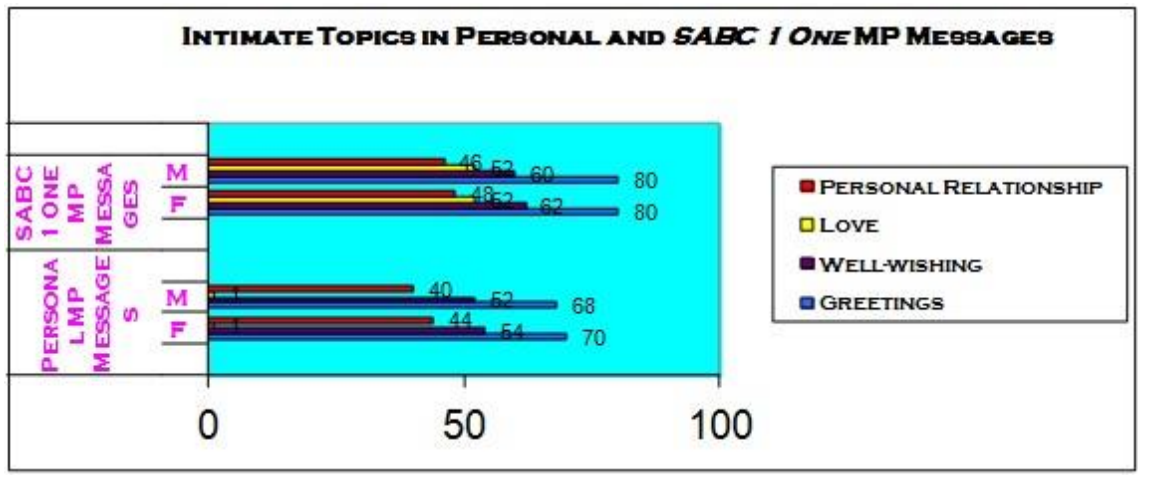

\section{Language Use: Passivity, Cooperativity and Accommodation}

Messages from all the data types were analysed for instances of passivity, cooperation and accommodation, and the frequencies of these instances were scored accordingly. The objective here was to establish which of the message senders - females or males - were likely to use more passive, cooperative and accommodating language. Figure 4 reflects the respective percentage usage frequencies of the three instances of language use by the various message senders from both the WDF and MP. 
Figure 4:

The percentage usage frequencies of the instances of passivity, cooperativity and accommodation by the message senders from both the WDF and MP

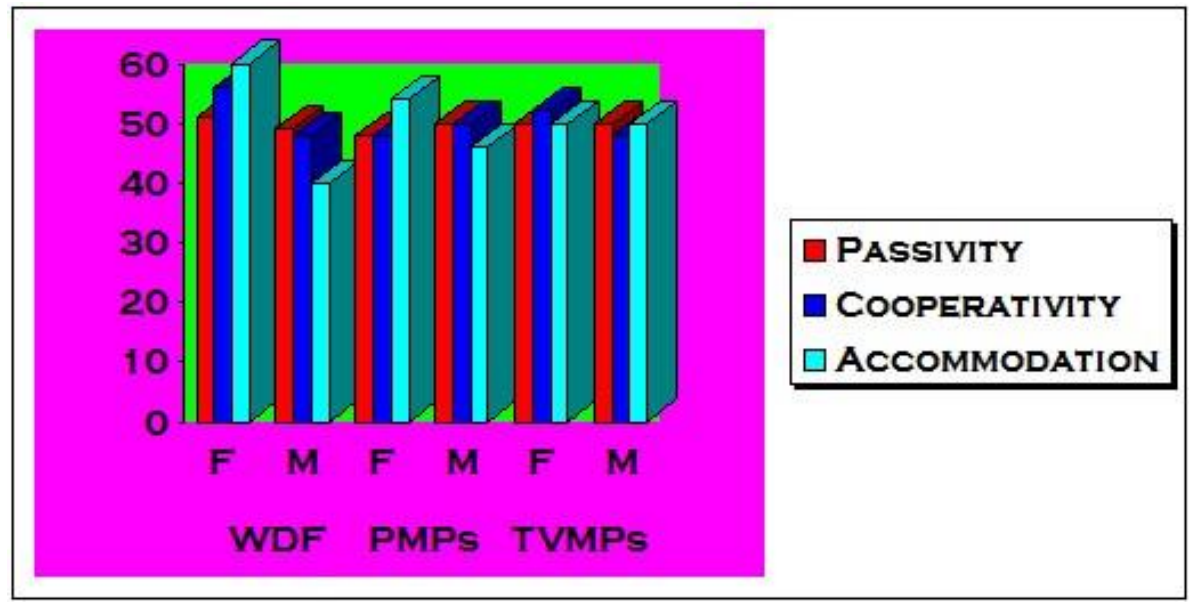

$F=$ females $; M=$ males $; W D F=$ web discussion forum; $P M P s=$ personal mobile phones; TVMPs = TV mobile phones (for SABC 1 One)

\section{Discussion}

Firstly, the main purpose of this study was to examine gender similarities and differences among adult males and females who used txt messages in a given online web discussion forum, and among adult males and females from South Africa who used mobile phone txt messages on their mobile phones on the one hand, and on a TV programme on the other hand. Secondly, the study explored how these three sets of users employed language and emoticons to present their identities and to express their personal feelings and experiences through these two forms of technologies. As such, it set out to test four hypotheses: 1) both males and females are likely to present themselves similarly in their messages often disclosing personal information such as either their real names, ID user names, or digital fake identities (pseudonyms), locations and personal background details such as their current jobs, professions, careers, etc.; 2) males tend to use less emoticons - and thus less expressive language - and tend to employ more active and resolute style of language than do females; 3 ) females tend 


\section{Chaka-Gender, Identity, and Language Use in WDF \& Txt Messages}

to discuss intimate topics more openly than males; and 4) females are more likely to use language that is passive, cooperative and accommodating than do males. In this sense, it was a comparative study looking, on the one hand, at both online and MP txt messaging identity construction between males and females. On the other hand, it investigated instances of gendered language use between males and females who posted WDF and MP txt messages.

\section{Personal Self-Disclosures}

In relation to personal self-disclosures as a variable, both female and male users of the WDF revealed their personal information more or less in the same way, even though there were fractionally varying degrees of disclosures by the two genders. For instance, in terms of percentage frequencies, female disclosures were relatively higher than males' in some of the personal information items investigated. This factor partly confirmed the first hypothesis as there was no significant percentage difference in the qualitative amount of personal information disclosed by both genders. Overall, both genders revealed a lot of personal information regarding emails, first and full names, ID user names, locations and personal background details (see Huffaker \& Calvert, 2005).

In the case of MP users, there were similar and differential degrees of disclosures of the personal information for both females and males in the two sets of data. For example, the most revealed items for personal data for both genders in the case of personal MPs were MP numbers (94\%/94\%) and nicknames $(54 \% / 60 \%)$, while the same items polled $0 \% / 0 \%$ and $50 \% / 74 \%$, respectively, for both genders in the case of SABC 1 One MP messages. Concerning the latter case in particular, the most disclosed items for personal information by both genders were first names $(88 \% / 90 \%)$, locations $(90 \% / 92)$, and nicknames $(50 \% / 74 \%)$. However, location fared badly for both genders in personal MP txt messages.

In addition, full names as an item scored $0 \%$ for both genders in all MP data sets. It is worth noting that despite all this, the qualitative disclosures of the personal information by both genders in all the different types of MP data seemed to negate the first hypothesis as the percentage disclosures for males were higher than those for females. Moreover, there were significant 
differences in some of the personal information that the users of both WDF and MP technologies disclosed. For example, full names scored highly for both genders in the WDF, while they scored $0 \%$ in the MPs. First names ranked highly for the two genders both in the WDF messages and in the $t x t$ messages sent to SABC 1 One whereas they featured less in the personal MP txt messages. For both genders location featured predominantly in the WDF and SABC 1 One MP txt messages, while it polled $0 \%$ in the personal MP txt messages.

In terms of gender and identity construction, the personal selfdisclosures made by the users of the two forms of technologies in this study imply that the two genders examined here constructed their identities both similarly and differently depending on the technology they used. For instance, on the one hand, if the different aspects of the personal information were regarded as constituting the different realms of one's identity, then there were instances when some of these realms assumed similar dimensions as exhibited by the two genders in these two technologies. On the other hand, there were instances when other realms of users' identities assumed different modalities as evinced again by these two genders. At the same time, the different forms of personal information the users displayed in the two technologies (e.g. real names, ID user names (pseudonyms), nicknames, passwords, pin numbers, etc) exemplified analogously - the different forms of identity (multiple cosmopolitan or diasporic digital identities) one could assume both online and through appropriating MP txt messaging.

\section{Emoticons, Typographic Symbols and Expressive Language}

The analysis of the use of emoticons by both females and males from both WDF and MP messages indicated that more females employed emoticons than their male counterparts. In the case of the WDF messages, the qualitative difference in terms of the usage frequencies between the two genders was significantly larger except for the emoticon signalling crying. However, regarding the MP messages, the difference between the two genders' use of the emoticons signifying happy and winking was marginally smaller, while both genders polled equally for crying and sad (see Table 1). The occurrence frequency of the emoticons for both genders in relation to the WDF seemed to confirm the first part of the second hypothesis that 
1143 Chaka-Gender, Identity, and Language Use in WDF \& Txt Messages

males use less emoticons than females (Huffaker \& Calvert, 2005). The same was also true of the use of the typographic symbols by both genders (see Table 2). On the contrary, the use of the emoticons by both sexes in the MP messages only partly confirmed this prediction (see Huffaker \& Calvert, 2005; D'Addario, n.d.; Thurlow \& Brown, 2003).

As is evident from Figure 1 above, the expressive language explored related only to the WDF users as there was not any instance of such language use that could be detected from the MP users. Here the occurrence frequencies indicated that, overall, female users polled higher than their male counterparts in all of the emotive traits associated with the expressive language. While this particular finding tended to confirm the first part of the second hypothesis, it nonetheless does not suggest that women were inherently more prone to be grateful, appreciative, apologetic and humorous than men in their use of the expressive language (D'Addario, n.d.; Herring, 2000; Huffaker \& Calvert, 2005).

\section{Gender and Intimate Topics}

The analysis of the intimate topics indicated both similar and varying degrees of engagement with such topics by both sexes in the WDF. For example, in respect of the discussion of items such as food and recipes, blogging, and colour and design, females scored higher than males, while the latter scored higher than the former with regard to computer viruses and hoaxes. However, with reference to andragogy, both genders scored more or less equally (with females scoring marginally higher), whereas concerning greetings, the two genders polled equal percentages. This in a way contradicts the third hypothesis that females tend to discuss intimate topics more openly than males (see Fig. 2). The percentage usage frequencies polled by both genders in the personal MP and $S A B C 1$ television programme One messages more than negate the third hypothesis in that here both genders ranked almost equally regarding the types of intimate topics in which they engaged (see Fig. 3). 


\section{Passive, Cooperative and Accommodating Language Use across Genders}

The analysis of the passive, cooperative and accommodating style of language was accordingly mounted using the Tropes V6.2 and DICTION 5.0 software packages. The use of accommodating language between the two genders differed fairly markedly in both the WDF and MP messages. Here the usage frequency for females was $60 \%$, while for males was $40 \%$. However, in the case of both the personal mobile phone and the SABC 1 One mobile phone messages, both genders used accommodating language almost equally (see Fig. 4). Moreover, the two genders used both passive and cooperative language equally across the three designated domains. That is, both genders tended to employ passive and cooperative language very nearly equally - barring the percentage difference in the case of accommodating language vis-à-vis the WDF and MPs (again see Fig. 4). This runs counter to the prediction embodied in the fourth hypothesis that females are more likely to use language that is passive, cooperative and accommodating than is the case with males.

\section{Conclusion}

This study set out to investigate both online gender and identity construction and language use and txt messaging gender and identity construction and language use among adult male and female users of a web discussion forum (Becomingwebhead), viewers of the SABC 1 programme, One, and private users of personal mobile phones. As such, as pointed out briefly above, it was a correlational study comparing, on the one hand, both online and MP txt messaging gender and identity construction between males and females. On the other hand, it explored instances of gendered language use between male and female users of these two forms of technologies. In one instance, it showed that both females and males investigated here tended to construct their identities - based on the personal information they disclosed - both similarly and differently depending on the form of technology they employed. In another instance, it indicated that the identities these two genders tended to display were multiple cosmopolitan or diasporic digital identities. 


\section{Chaka-Gender, Identity, and Language Use in WDF \& Txt Messages}

In addition, the study showed that in both the WDF and MP messages, more females tended to employ emoticons than did males. This was much more pronounced in the case of the WDF messages than in the case of the MP messages. The same was true of the emotive traits related to expressive language. With reference to gender and intimate topics, the study discovered that the two genders engaged in intimate topics in varying degrees. That is, it was not females alone that openly discussed such topics; rather, males also tended to do so. The study also discovered that both genders tended to employ passive and cooperative language (and accommodating language to some degree) very nearly similarly.

\section{Limitations and Recommendations}

The data used in this study were very limited and too varied to constitute a coherent whole. As such, the findings emerging from them are highly contextual and tentative. Besides, researching issues related to gender and identity is a highly subjective task involving personal biases and preconceptions that can colour one's treatment of these issues. Moreover, identity in particular, is a problematic and controversial variable to pin to any one specific and clear definition. Added to this is the fact that equating gender and identity construction to a disclosure or non-disclosure of one's personal information is tantamount to a simplistic and superficial representation of these two concepts (see Huffaker \& Calvert, 2005). Furthermore, at best, studying gender, identity and language use in domains such as WDFs (online technologies) and MPs (mobile txt messaging technologies) entails inherent shortcomings as users can post messages and send $t x t$ messages which at times have little to do with the type of gender they belong to or with their gender orientation. At worst, users in domains such as these can fake who they are (their identities), what genders they are, and what their sexual orientations are. So, as a result, more research is needed to unearth the intricacies of and to come to grips with the gender and language use - with the attendant multiple cosmopolitan or diasporic digital identities - of the users of the technologies such as the ones studied in this article. In particular, more correlational longitudinal and crosssectional studies are needed to further investigate gender and identity 
construction and instances of gendered language use on different current and emerging technologies.

\section{Declaration of Interest}

The author declares that he has no financial or personal relationship(s) that may have inappropriately influenced him in writing this article.

\section{References}

Bhabha, H. (1994). The location of culture. London: Routledge.

Bucholtz, M. (1999). Bad examples: transgression and progress in language and gender studies. In M. Bucholtz, A.C. Liang, \& L.A. Sutton (Eds.), Reinventing identities: The gendered self in discourse (pp. 3-20). Oxford: Oxford University Press.

Burgess, C. (2002). The relevance of the bridging of discourse and feminist theory for Japan. Retrieved from http://wwwsshe.murdoch.edu.au/intersections/issue7burgess.html

Butler. J. (1997). Excitable speech: A politics of the performative. London: Routledge.

Calcutt, A. (2001). Generation txt: mixed messages. Retrieved from http://www.spiked-online.com/Articles/0000000054DF.htm

Cameron, D. (1992). Feminism \& linguistic theory. London: MacMillan Press.

Cameron, D. (1997). Performing gender identity: young men's talk and the construction of heterosexual masculinity. In S. Johnson, \& U.H. Meinhof (Eds.), Language and masculinity (pp. 47-64). Oxford: Blackwell.

Cameron, D. (Ed.) (1998). The feminist critique of language: A reader. London: Routledge.

Castells, M. (2000). The rise of the network society, the information age: Economy, society and culture. Oxford: Blackwell.

Coates, J., \& Cameron, D. (Eds.) (1988). Women in their speech communities. London: Longman.

Crawford, M. (1995). Talking difference: On gender and language. London: Sage.

Crystal, D. (2001). Language and the Internet. Cambridge: Cambridge University Press. 
1147 Chaka-Gender, Identity, and Language Use in WDF \& Txt Messages

D'Addario, K.P. (n.d.). Do those little "smiley-faces" in electronic mail have an effect on the reader? Retrieved from http://www.rpi.edu/ daddak/emoticonpaper.html

Diamandaki, K. (2003). Virtual ethnicity and digital diasporas: identity construction in cyberspace. Global Media Journal, 2(2).

Donath, J.S. (1996). Identity and deception in the virtual world. Retrieved from

http://smg.media.mit.edu/peopleJudith/Identity/IdentityDeception.html

Eckert, P., \& McConnell-Ginet, S. (1999). New generalizations and explanations in language and gender research. Language and Society, 28(2), 185-201. Retrieved from https://www.cambridge.org/core/article/new-generalizations-andexplanations-in-language-and-genderresearch/A2FD545AA80177B81B5BBE1B87088B60

Erasmus, E. (1998). The relationship between postmodernism and feminism: A construction of sites of engagements. Acta Academica, 30(1), 1-31.

Farina, F., \& Lyddy, F. (2011). The Language of text messaging: "linguistic ruin" or resource? The Irish Psychologist, 37(6), 144-149. Retrieved from http://eprints.nuim.ie/2681/1/FF_Text_Messaging.pdf

Geertsema, S., Hyman, C., \& van Deventer, C. (2011). Short message service (SMS) language and written language skills: educators' perspectives. South African Journal of Education, 31, 475-487. Retrieved from http://www.scielo.org.za/pdf/saje/v31n4/v31n4a02.pdf

Griffiths, M. (1995). Making a difference: feminism, post-modernism and the methodology of educational research. British Educational Research Journal, 21(2), 219-235.doi: 10.1080/0141192950210207

Heckman, R., \& Annabi, H. (2005). A content analytical comparison of learning processes in online and face-to-face case study discussions. Retrieved from http://jcmc.indiana.edu/vol10/issue2/heckman.html

Herring, S.C. (2000). Gender differences in CMC: Findings and implications. Computer Professionals for Social Responsibility, 18(1). Retrieved from http://www.cpsr.org/publications/newsletters/issues/2000/Winter2000/her ring.html 
Herring, S.C., Kouper, I., Scheidt, L.A., \& Wright, E.L. (2004). Women and children last: the discursive construction of weblogs. In L.J. Gurak, S. Antonijevic, L. Johnson, C .Ratliff, \& J. Reyman (Eds.), Into the blogosphere: Rhetoric, community, and culture of weblogs. Retrieved from http://blog.lib.umn.edu/blogsphere/women and children.html

Huffaker, D.A. (2004). Spinning yarns around a digital fire: storytelling and dialogue among youth on the Internet. First Monday, 9(1). Retrieved from http://www.firstmonday.dk/issues/issue9_1/huffaker/index.html

Huffaker, D.A., \& Calvert, S.L. (2005). Gender, identity and language use in teenage blogs. Journal of Computer-Mediated Communication, 10(2). Retrieved from http://jcmc.indiana.edu/vol10/issue2/huffaker.html

Jones, S.G. (Ed.) (1997). Virtual culture: Identity and communication in cybersociety. London: Sage.

Katz, J.E., \& Aakhus. M. (2002). Conclusion: making meaning of mobiles: a theory of apparatgeist. In J.E. Katz, \& M Aakhus (Eds.), Perpetual contact: Mobile communication, private talk, public performance (pp. 301-318). Cambridge: Cambridge University Press.

Lakoff, R. (1975). Language and woman's place. New York: Harper \& Row.

Lather, P. (1992). Post-critical pedagogies: a feminist reading. In J .Gore, \& C. Luke (Eds.), Feminisms and critical pedagogy (pp. 120-137). London: Routledge.

Lee, C. (2003). How does instant messaging affect interaction between the genders? Retrieved from http://www.stanford.edu/class/pwr325/group2/projects/lee.html

Levinson, S.C. (1983). Pragmatics. Cambridge: Cambridge University Press.

Leung, L., \& Wei, R. (2000). More than just talk on the move: uses and gratifications of the cellular phone. Journalism and Mass Communication Quarterly, 77(2), 308-320.

Lewis, R., \& Mills, S. (Eds.) (2003). Post-colonial feminist theory: A reader. Edinburgh: Edinburgh University Press.

Ling, R., \& Yttri, B. (2002). Hyper-coordination via mobile phones in Norway. In J. Katz, \& M. Aakhus (Eds.), Perpetual contact: Mobile communication, private talk, public performance (pp. 139-169). Cambridge: Cambridge University Press. 
1149 Chaka-Gender, Identity, and Language Use in WDF \& Txt Messages

Liwei, G. (2001). Digital age, digital English. English Today, 17(3), 17-23. Lowe, W. (2003). The statistics of text: new methods for content analysis. Retrieved from

http://people.cbrss.harvard.edu/ wlowe/Publications/content.pdf

Luke, C. (1992). Feminist politics in radical pedagogy. In J. Gore, \& C. Luke (Eds.), Feminisms and Critical Pedagogy (pp. 25-53). New York: Routledge.

Marney, R. (2005). Case study: online identities. Retrieved from http://www.people.virginia.edu/ rmm4y/casestudy.html

McArthur, T. (2000). Netcronyms and emoticons. English Today, 16(4), 40.

Microsoft Corporation. (2005). Microsoft's vision for an identity metasystem.

Retrieved

from

http://msdn.microsoft.com/library/default.asp?url=/library/en-

us/dnwebsrv/html/identitymetasystem.asp

Mills, S. (2003a). Caught between sexism, anti-sexism and "political correctness": feminist negotiations with naming practices. Discourse and Society, 14(1), 87-110. doi:10.1177/0957926503014001931

Mills, S. (2003b). Third wave feminist linguistics and analysis of sexism. Retrieved from http://www.shu.ac.uk/daol/articles/open/2003/001/mills/2003001paper.html

Mills, S. (2003c). Gender and politeness. Cambridge: Cambridge University Press.

Murphy, E. (2001). Investigating the multiple worlds of teaching through multiloguing. Educational Technology \& Society, 4(3). Retrieved from http://ifets.ieee.org/periodical/vol_3_2001/murphy.html

Njemanze, Q.U. (2012). The SMS style of communication: implications of language usage among Nigerian university students' communication. Journal of Communication, 3(1), 17-23.

Norrick, N. (1991). On the organization of corrective exchanges in conversation. Journal of Pragmatics, 16, 59-83. doi:10.1016/03782166(91)90005-I

Oyinloye, G.O. (2009). Assessing the need for mobile communication mediated instructional strategy in the teaching of writing skills. Retrieved from http://medwelljournals.com/fulltext/ijsc/2009/39-44.pdf 
Pachler, N., \& Daly, C. (2009). Narrative and learning with Web 2.0 technologies: towards a research agenda. Journal of Computer Assisted Learning, 25, 6-18. doi: 10.1111/j.1365-2729.2008.00303.x

Persson, P. (2003). ExMS: an animated and avatar-based messaging system for expressive peer communication. Retrieved from http://www.perpersson.net/Publications/group2003.pdf

Petrina, S. (1998). The politics of research in technology education: a critical content and discourse analysis. Journal of Technology Education, 10(1), 27-57.

Piller, I. (2001). Identity construction in multilingual advertising. Language in Society, 30, 153-182.

Poynton, C. (1993). Grammar, language and the social: poststructuralism and systemic-functional linguistics. Social Semiotics, 3(1), 1-21. Doi: 10.1080/10350339309384407

Rassool, N. (1998). Postmodernity, cultural pluralism and the nations-state: problems of language rights, human rights, identity and power. Language Sciences, 20(1), 89-112. doi:10.1016/S0388-0001(97)00014-4

Riggins, S.H. (1997). The rhetoric of othering. In S.H. Riggins (Ed.), The language and politics of exclusion: Others in discourse (pp. 1-3-0). Thousand Oaks: Sage.

Sacks, H. (1994). Lectures on conversation. Oxford: Blackwell.

Sadiqi, F. (2003). Gender and language in Morocco. Leiden: Brill.

Simpson, A. (1997). It's a game!: the construction of gendered subjectivity. In R. Wodak (Ed.), Gender and Discourse (pp. 197-224). London: Sage.

Stalder, F. (2000). Digital identities - patterns in information flows. Retrieved from http://felix.openflows.org/html/digital_identity.html

Swann, J. (2002). Yes, but is it gender? In L. Litosseliti, \& J. Sunderland (Eds.), Gender identity and discourse analysis (pp. 43-67). Amsterdam: John Benjamins

Tannen, D. (1990). You just don't understand: Women and men in conversation. London: Virago.

Tapscott, D. (1998). Growing up digital: The rise of the net generation. Washington, DC.: McGraw-Hill.

Thurlow, C., \& Brown, A. (2003). Generation txt? the sociolinguistics of young people's text-messaging. Retrieved from http://www.shu.ac.uk/daol/articles/v1/n1/a3/thurlow2002003-paper.html 
1151 Chaka-Gender, Identity, and Language Use in WDF \& Txt Messages

Thurlow, C., Lengel, L.B., \& Tomic, A. (2004). Computer mediated communication: A critical exploration of social interaction online. London: Sage.

Turkle, S. (1995). Life on the screen: Identity in the age of the Internet. New York: Simon \& Schuster.

Turkle, S. (1996). Who am we? Wired Magazine, 4(1). Retrieved from http://www.wired.com/wired/archive/4.01/turkle_pr.html

Weedon, C. (1987). Feminist practice and poststructuralist theory. London: Blackwell.

Wodak, R. (1997). Introduction some important issues in the research of gender and discourse. In R ,Wodak (Ed.), Gender and Discourse (pp. 120). London: Sage.

\section{Chaka Chaka, Associate Professor}

Contact address: Department of English Studies. College of Human Sciences. PO BOX 392. University of South Africa. 0003 South Africa.

E-mail address: chakacp@unisa.ac.za 